\title{
Digitalization and City Center Resilience. Exploring Visitors' Perceptions in Leipzig, Germany
}

https://doi.org/10.1515/zfw-2021-0003

Received: 28. January 2021; accepted: 17. October 2021

Zusammenfassung: Im vorliegenden Artikel wird am Beispiel Leipzigs analysiert, welche Rolle Digitalisierung für die Resilienz von Innenstädten spielt. Fokusgruppeninterviews verdeutlichen, dass digitale Anwendungen zur Attraktivität eines Innenstadtbesuchs und so zur Resilienz der Innenstadt beitragen können. Der vor diesem Hintergrund entwickelte Prototyp, eine digitale Karte der Leipziger Innenstadt, wird mit 70 go-along Interviews getestet. Die Interviews zeigen, dass eine Verknüpfung digitaler Funktionen mit lokalspezifischen Informationen die resiliente Innenstadt fördern.

Abstract: This article deals with digitalization as a contribution to city center resilience, using Leipzig as an example. Focus group interviews illustrate that digital applications can attract to visit the city center and thus contribute to city center resilience. To reinforce these findings, the authors develop a prototype of a digital map covering Leipzig's city center that is tested by means of 70 go-along interviews. The interviews show that linking

*Corresponding author: Katrin Schade, Leipzig University, Institute of Urban Development, Grimmaische Straße 12, 04109 Leipzig, Germany, +49 3419733748 ORCID ID 0000-0001-6456-7477, E-Mail: katrin.schade@uni-leipzig.de

Andre Müller, Universität Leipzig, Wirtschaftswissenschaftliche Fakultät, Institut für Wirtschaftsinformatik, Leipzig, Germany, E-Mail: amueller@wifa.uni-leipzig.de

Eric Holdack, HHL Leipzig Graduate School of Management, Faculty of Marketing Management, Leipzig, Sachsen, Germany, E-Mail: eric.holdack@hhl.de

Marcus Hübscher, Leipzig University, Institute of Urban Development, Grimmaische Straße 12, 04109 Leipzig, Germany, +49341 9733768, ORCID-ID 0000-0003-0488-7297,

E-Mail: huebscher@wifa.uni-leipzig.de

Katja Lurie, HHL Leipzig Graduate School of Management, Faculty of Marketing Management, Jahnallee 59, Leipzig 04109, Sachsen, Germany, E-Mail: katja.lurie@hhl.de

Juana Schulze, Leipzig University, Institute of Urban Development, Grimmaische Strasse 12, 04109 Leipzig, Germany, E-Mail:

juana.schulze@uni-leipzig.de digital functions and location-specific information thereby can be effective regarding city center resilience.

Keywords: city center, retail, resilience, digitalization, Leipzig

\section{Introduction}

Digitalization, understood as an ongoing "integration of digital technologies" (Hagberg et al. 2015, 696), is an essential achievement of the 21st century and challenges the established urban structures and patterns (Haefner/ Sternberg 2020). In city centers, the impacts of digitalization are most evident in the retail sector, as one of the dominant urban functions. The share of e-commerce of the total trade volume in Germany has risen steadily since the initiation of online retail (HDE/IFH, 2019). Covid-19 has even accelerated this transformation. Sales in e-commerce have grown $23 \%$ from 2019 to 2020 in Germany (HDE/IFH 2021) while, for many weeks, local shops in "non-essential” branches were closed (Appel/Hardaker 2021).

Retail digitalization constitutes polarizing urban transformation processes. On the one hand, e-commerce affects local retailers and eventually determines regional customer flows and frequencies. For example, an increasing number of customers prefers to order products conveniently at home, even in a pre-Covid-19 context (Balsas 2014; Barata-Salgueiro/Erkip 2014; Ozuduru et al. 2014; Wrigley/Dolega 2011). Simultaneously, with Covid-19 restrictions, customers often have no other option but to shop online (Villa/Monzón 2021; Nanda et al. 2021). Therefore, e-commerce entails risks for city centers such as the loss of local retailers, particularly small owner-managed shops, resulting in shop vacancies (Schade et al. 2018). On the other hand, there are efforts of pure online players such as Amazon or Zalando to open stores in city centers of large cities and thus to be visible offline, too (Schade/ Hübscher 2018).

Omnichannel efforts do not only apply to large pure online retailers but also to local retailers (Schade et al. 2018). Within local retailers' digitalization strategies, 
digital applications such as location-based services provide new opportunities to capture customers' potential (Heinemann/Gaiser 2016). However, it remains unclear whether digital applications will increase the attractiveness to visit the city center or whether they are more likely to benefit online shopping. After all, one of the main concerns of the New Leipzig Charter 2020 is to promote accessible, multifunctional central urban spaces for all people (BMI 2020).

Against this background, the paper analyzes factors that attract to visit the city center (1). With the New Leipzig Charter 2020 in mind, the researchers argue that visiting the city center is crucial for its resilience. The paper also questions how digitalization can become such a factor and contribute to the concept of resilience (2). Leipzig is chosen as a case study, mainly because the city shows strong dynamics in urban development. Leipzig has been Germany's fastest-growing city during the last decade (Hübscher et al. 2021). Paradoxically, the vacancy rate in retail has risen dramatically in the city center, even before the global pandemic. The vacancy rate peaked in 2019 at $14 \%$ - a new negative record in the history of Leipzig's retail monitoring (Stadt Leipzig 2020). Due to the pandemic, this number has even skyrocketed to $19 \%$ in summer 2021 (Schmidt 2021). This illustrates how Covid-19 must be regarded as a catalyst for the already struggling retail sector in city centers (Beckers et al. 2021).

On that basis, two research aims are presented. The first aim is to identify factors that attract to visit Leipzig's city center from the visitor's perspective.

- For this purpose, the authors scrutinize the strengths and weaknesses of Leipzig's city center with the help of focus group interviews that represent different types of visitors.

- The authors then derive success factors and challenges that may or may not encourage people to visit Leipzigs' city center.

One main outcome of the focus groups is the need for a digital information platform as one possible instrument to encourage a city center visit. Hence, the authors further focus on this aspect. The second aim of the study is to explore how digitalization fosters the city center's attractiveness and thus contributes to its resilience. Following a citizen-oriented approach (Korzer et al. 2020),

- the authors design a prototype of a digital map as an essential part of a digital information platform, covering Leipzig's city center, and, present it to visitors on-site.

- 70 qualitative go-along interviews help to evaluate the prototype and identify visitors' suggestions to improve it. Four types of visitors are developed to help adapt the prototype to the needs of different user groups: time-efficient visitors, non-digital visitors, digital visitors, and motivational visitors.

- On that basis, the study develops requirements for the frequent use of a commercial version of the prototype, to attract visitors to Leipzig's city center and contribute to its resilience.

\section{Resilience, Urban Development and Digitalization}

"Urban resilience generally refers to the ability of a city or urban system to withstand a wide array of shocks and stresses" (Leichenko 2011, 164). Originating from educational research (Wang/Gordon 1994) and refined within environmental research, the concept of resilience is applied to different fields in urban development (Kabisch et al. 2018). The fields share the idea of resilience, to implement adaptation mechanisms and instruments (Leichenko 2011) to "retain essentially the same function, structure, identity, and feedbacks" (Walker et al. 2004, 2). The city center as key space here is "generally denser, older and more heterogeneous" than other districts and reveals chances and challenges concerning its resilience (DeVerteuil 2016, 11). In the following, the development of retail as a central function in city centers is described as stress factor. Covid-19 and the lockdown protocols reinforce this effect. While digitalization causes challenges for local retail, digital applications also serve as solutions for vulnerable city centers and can promote their resilience.

\subsection{Retail Development as a Stress Factor for City Centers}

There is a strong link between European city centers and retail caused by interdependencies and synergy effects. This is why a change in local retail formats has always led to a change of structure, quality, and consumer frequency within German city centers (Stepper 2016).

Online retail becomes more important for customers. Adopting so-called 'omnichannel' (Jones/Livingstone $2018,50)$ strategies, local stores increasingly offer their products online. For customers, this process creates synergies in both directions. At best for local retailers, customers inform themselves online before buying in stores and, at worst, buy online after getting advice in stores. The latter development increasingly reduces the histori- 
cally grown unique selling proposition of city centers as the most important retail market places. These considerations imply that retail will no longer be the primary function of city centers (Sperle 2012). Consequently, there is an increasing need to identify innovative approaches for a redefinition of city center functions and attractiveness (Gerber 2018).

However, studies on how city centers can be more resilient to the impacts of online consumption are rare. Singleton et al. (2016) look at factors that attract shopping locations. Other authors have stated an increasing desire for vibrant and diverse urban spaces with a rich, authentic street life (Brooks 2001). Accordingly, recent research stresses the need for entertainment in the city (Nichols 2011). More novel studies, therefore, focus on the perceived attractiveness of urban spaces for different stakeholders, such as residents, tourists, entrepreneurs, and investors (e. g., Wahlberg 2016; Coca-Stefaniak/Carroll 2015; Hart et al. 2013; Pazder 2011; Weltevreden/van Rietbergen 2007; Litvin 2005; Sandahl/Lindh 1995). Studies from Poland, the Netherlands, and Sweden demand mixed functions to maintain city center attractiveness. This includes shops, services, activities, entertainment, parks, architecture, workplaces, and housing (Öner 2017; Wahlberg 2016; Hart et al. 2013; Pazder 2011; Weltevreden/van Rietbergen 2007).

Attractiveness can include tangible (e.g., infrastructure, housing, shops, and parks) and intangible (e.g., emotions, and values) aspects (Zenker 2011). Successfully co-locating the elements mentioned above means to balance the commercial function of city centers with cultural heritage (Coca-Stefaniak/Carroll 2015; Litvin 2005). In tourism studies, researchers demand to create synergies between commercial facilities, cultural heritage, and historical sights (e. g., Vural-Arslan et al. 2011; Litvin 2005). Creating these synergies in city centers, though, implies complex interactions between visitors, industries, and the various city center functions (Brańka et al. 2016, Gibson/ Hardman 1998). However, by creating synergies and highlighting other uses besides retail, urban development can play a crucial role to regain attractive city centers.

\subsection{Digitalization Strategies: Reflecting on City Center Resilience}

Digitalization plays a decisive role as an information and networking medium for city centers (Bartelheimer et al. 2018; Demko-Rihter/Ter Halle 2015). In this paper, the authors refer to digitalization as a conceptual approach such as e-commerce or essential digital applications that lead to urban transformation processes. Digitization is understood as the practical process to digitize analog data, for example, within digital applications (such as digitizing payment processes).

In recent literature dealing with resilience, urban development and digitalization, researchers phase various stakeholder-oriented strategies (Fig. 1). Sparks $(2021,9)$ deals with National public policies towards resilient towns and retail in Scotland. Ideas for digital policies like "introducing a digital tax" but also supporting the development of "digital skills and uses in towns" illustrate the polarizing effect of digitalization on urban space.

According to Sharifi et al. (2021, 5), city administrations are responsible to develop "digital platforms for integrated data sharing and communication, and smart surveillance systems" (city-as-a-platform approach, Anttiroiko 2016). The authors divide between four resilience abilities: Planning/Preparation, Absorption, Recovery, and Adaptation and recapitulate digitalization processes in the light of Covid-19 (ibid.). Mainly the resilience abilities "planning/ preparation" and "adaptation" focus on digitalization; first, to provide smart city infrastructure (such as VR/AR, 3D-printing, communication networks, ...) and second, to accelerate the transition towards digitalization (ibid.). Korzer et al. (2020) mention the development of cities' urban data platforms. The city of Hamburgs' platform is a revealing example in Germany. A central application of the cities' platform is a digital map (Geo-Portal Hamburg 2021) which includes digitized data of the city, referring to areas such as public utilities, waste management, administration, health, construction, mobility, logistics, transport, business et cetera. Retail, however, does not yet play a major role there.

Holdack et al. (2020), Wichert et al. (2019), and Rao (2019) deal with retailers and omnichannel strategies (Wichert et al. 2019). Linking retail and urban development to resilience strategies, Rao (2019) mentions the ability of retailers to reduce the size of their shops to remain competitive in the city, but also to compete with pure online retailers. Holdack et al. (2020) focus on digital tools for retailers' such as AR glasses, to remain attractive for customers. Schade et al. $(2018,1)$ analyze Local Online Platforms (LOPs) that review different stakeholders but primarily focus on retailers in the city center. Some LOPs already create synergies between different city center functions and characteristics, as Vural-Arslan et al. (2011) and Litvin (2005) recommend. However, LOPs' appearance and content is too diverse to reveal a common strategy apart from retail resilience (ibid.). 


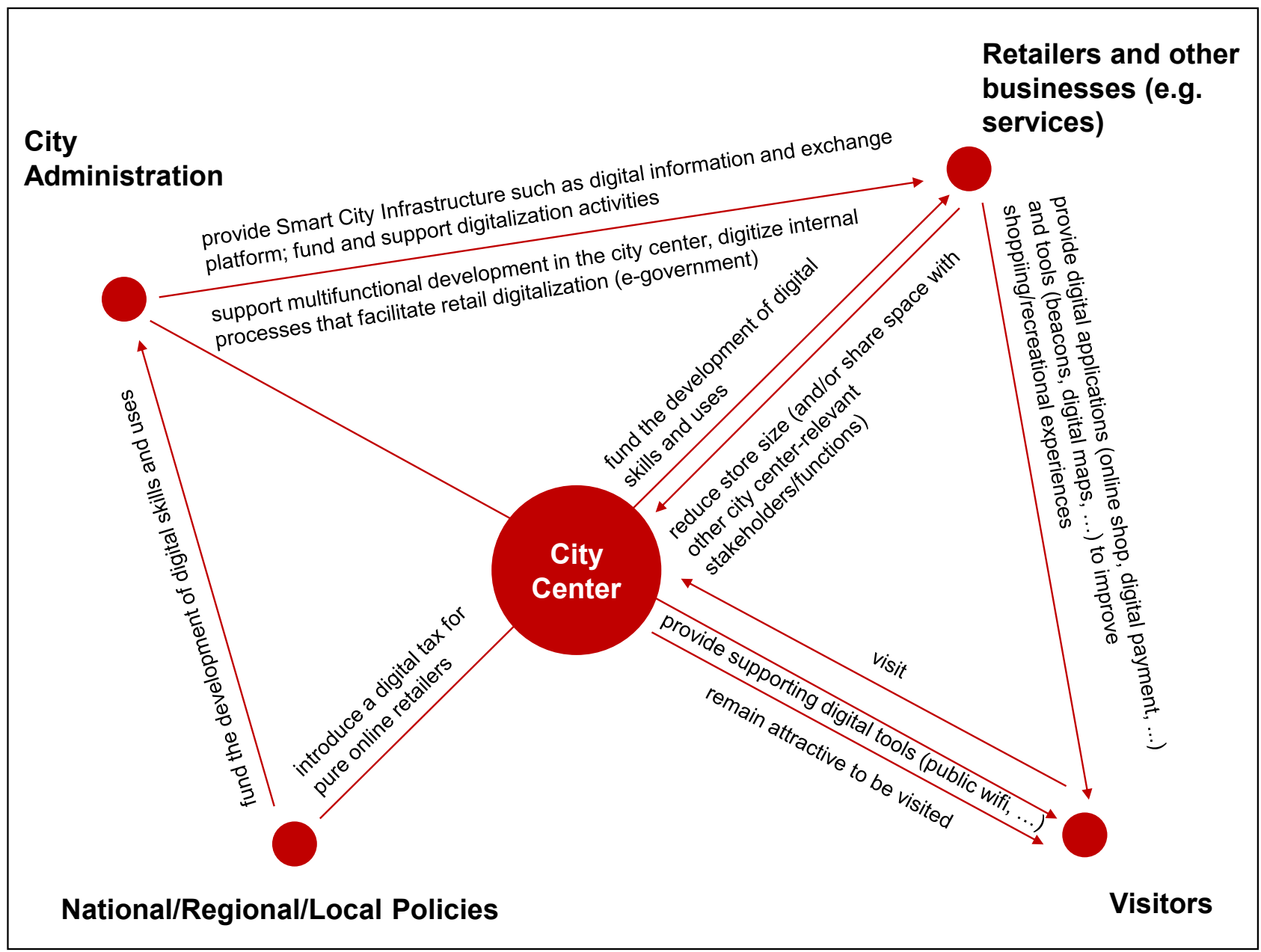

Figure 1: Stakeholder-oriented (digitalization) strategies to promote City Center Resilience (Sparks 2021, Sharifi et al. 2021, Korzer et al. 2020, Holdack et al. 2020, Wichert et al. 2019, Rao 2019, Schade et al. 2018) (own elaboration).

In summary, there are several strategies to support city center resilience by increasing their attractiveness for visitors. Digitalization strategies offer a variety of solutions and address different stakeholders and functions of the city center, although the demand-sided perspectives often remain unclear. How visitors perceive the city center and the impact of digitalization is part of this study. Therefore, city center resilience is defined as the ability of city centers to attract visitors and remain accessible to diverse people (BMI 2020, Brooks 2001). In this context, digitization is defined as a tool of digitalization that supports the attraction to visit the city center (Singleton 2016).

\section{Methodological Approach}

This paper focuses on Leipzig (Germany) as a case study for two reasons. Firstly, Leipzig is a German second-tier city representing urban spaces that are often neglected in studies of digitalization (Korzer et al. 2020). Secondly, Leipzig has experienced divergent trends of urban development, which makes it a compelling test case for technical and empirical methods as digitalization adds to the already ongoing transformation processes.

\subsection{Divergent Trends Leave Leipzig's City Center Vulnerable}

After the German reunification, Leipzig's population declined from 511,000 in 1990 to only 437,000 in 1998, which is a loss of $14.5 \%$. Thereafter, its population grew 
significantly by $22 \%$ until 2018 . The city currently counts more than 600,000 inhabitants (Stadt Leipzig 2021). Since 2010, Leipzig has even shown the strongest increase among German large cities (BBSR 2019).

This demographic development contributes to the dynamics in the retail sector which has grown about $74 \%$ during the last 20 years in terms of sales area (City of Leipzig 2019). However, there are significant spatial disparities on a small scale. Strong suburbanization processes have undermined the traditional dominance of Leipzig's city center as the leading retail agglomeration during the 1990ies (Herfert/Röhl 2001). This included the construction of several large-scale shopping centers at the outskirts of the urban core (Nuissl et al. 2005, 26). However, re-urbanization processes (Haase et al. 2012) and the production of inner-city large-scale retail projects contribute to the attractiveness of Leipzig's city center as a shopping area. In 2018, Leipzig's city center even became Germany's most popular retail area from the visitor's point of view (IFH 2019). Despite that, the center has to cope with a persistent and growing number of retail vacancies, affecting both prime and secondary locations. Currently, Leipzig's vacancy rate is the highest among the nine largest German cities (Wichner/Sörgel 2019).

\subsection{Focus Group Interviews: Identifying Solutions for Leipzig's City Center}

To identify factors supporting the resilience of Leipzig's city center, the authors firstly conduct focus group interviews (qualitative approach). This citizen-oriented method allows to explore participants' opinions and perceptions towards the city center on a group level (Jakobsen 2012; Hines 2000). The focus group interviews also include interviewees who do not necessarily visit the center but have a relevant opinion about the center's attractiveness. This helps to identify inhibiting factors to visit the city center and provide approaches for improvement. The approach encourages the participants to express and share their experiences on the topic (Glerean et al. 2019;
Vainikka 2015). It also helps to challenge, question, and validate the statements of the participants in a conversational manner (Jakobsen 2012; Hopkins 2007). The interviewers keep the questions open and broad, so that the interviewees develop diverse and unbiased answers.

The authors conduct a total of five focus group interviews (Table 1). The interviews include between four and six participants, which correspond to the most common requirements for this method (Hopkins 2007). The authors choose a differentiation of groups based on consumer segments (see Table 1). Previous research shows that members of the same segments tend to have homogeneous requirements and a similar focus on the retail environment. The division of the groups therefore follows the requirements of the method that focus groups "should be homogeneous in respect of the relevant selection criteria, but unknown to each other" (Tonkiss 2001, 201) The fifth group is heterogeneous and serves as a control group. In total, 26 interviewees participate in the study.

Two researchers (moderator and co-moderator) conduct interviews with all five focus groups, which last between 60 and 90 minutes. A third independent observer takes field notes in addition to the audio records of the interviews to transcribe them. The moderators use a semi-structured guide to question the participants and to ensure a general consistency between the groups (Patton 2002). The addressed issues conform with the following objectives: 1) to analyze the current development of the city center of Leipzig, 2) to identify the perceived strengths and weaknesses during a shopping visit in the city center, and 3) to discuss suggestions for improvement.

The authors code and analyze the collected data from the transcription of the audio record using the qualitative data analysis tool Atlas.ti. Thereby, they choose an inductive approach to merge the raw data into a structured framework (code tree; Thomas 2006). The study uses inductive content analysis as a method. This is particularly suitable for texturing perceptions, personal evaluations, and opinions of the participants and, thus, help to achieve the research objectives (Glerean et al. 2019; Mayring 2000, Table 2).

Table 1: Overview of the focus groups (own elaboration).

\begin{tabular}{llll}
\hline $\begin{array}{l}\text { Focus } \\
\text { group }\end{array}$ & characteristics & $\begin{array}{l}\text { number of } \\
\text { interviewees }\end{array}$ & denomination of interviewees \\
\hline 1 & single people in full-time (or part-time) employment without children & 5 & $\mathrm{P} 111 ; \mathrm{P} 211 ; \mathrm{P} 311 ; \mathrm{P} 411 ; \mathrm{P} 511$ \\
2 & working couples without children & 6 & $\mathrm{P} 112 ; \mathrm{P} 212 ; \mathrm{P} 312 ; \mathrm{P} 412 ; \mathrm{P} 512 ; \mathrm{P} 612$ \\
3 & working couples with children & 4 & $\mathrm{P} 113 ; \mathrm{P} 213 ; \mathrm{P} 313 ; \mathrm{P} 413$ \\
4 & single parents & 5 & $\mathrm{P} 114 ; \mathrm{P} 214 ; \mathrm{P} 314 ; \mathrm{P} 414 ; \mathrm{P} 514$ \\
5 & heterogeneous group & 6 & $\mathrm{P} 115 ; \mathrm{P} 215 ; \mathrm{P} 315 ; \mathrm{P} 415 ; \mathrm{P} 515 ; \mathrm{P} 615$ \\
\hline
\end{tabular}




\subsection{Prototype and Go-Along Interviews: Digitalization as a Solution?}

A key finding of the focus group interviews is that participants consider a digital information platform to be necessary that both supports shopping and helps to organize the trip. On that basis, the authors develop a prototype of a digital map as an essential part of a digital information platform, mapping certain functions and information of Leipzig's city center. The authors digitize local information of Leipzig's city center that they and the focus group participants find relevant. To review the success of this prototype, the authors conduct qualitative short interviews (go-along) in Leipzig's city center. The aim of the interviews is to question if the proposed contents of the map increase the attractiveness of Leipzig's city center. Second, the researchers aim to analyze similarities and differences between visitors from which certain types of visitors can be mapped. To identify types of visitors, a quantitative approach is used. Third, these findings help to identify further requirements for a commercial version of the prototype.

The interviews are conducted in Leipzig's Petersstraße, a prime retail location, from November $9^{\text {th }}$ until $17^{\text {th }}$ (2018) between 9 a.m. and 8 p.m. (Fig. 2). Consequently, the results are limited as only visitors are reached who are already motivated to visit the city center. However, the authors put the focus on being able to test the prototype in the city center to guarantee a realistic setting.

The necessity to design this prototype derives firstly from the lack of traditional map providers (such as google maps) to offer information beyond classical business references. Secondly, it is particularly this lack of information that is identified as one of the major requirements in the focus group interviews (see following section). Therefore, the primary goal is to map this type of information in an accessible way and put this prototype to the test under real-life conditions.

The prototype supports the go-along interviews because the interviewees are asked to use it (Fig. 3). The objective is to guarantee high stability over the runtime and usability with different end devices (such as desktop computers, smartphones, tablets) as well as accessibility via the Internet. By using industry standards for development (Java, Linux) and by operating within a local university's infrastructure, the authors achieve this goal. Based on Open Street Map, a website displays the collected spatial information. In addition, local retailers from the city center of Leipzig are integrated by putting them on

Table 2: Overview of the code system (own elaboration).

\begin{tabular}{|c|c|c|c|}
\hline Main categories & Sub-categories & Codes & References \\
\hline \multirow[t]{6}{*}{ Requirements } & recreation locality & 6 & 27 \\
\hline & need for information & 5 & 17 \\
\hline & Facilities & 7 & 17 \\
\hline & experience and diversity & 7 & 12 \\
\hline & improvement of service features & 18 & 35 \\
\hline & requirements for retail & 16 & 20 \\
\hline \multirow[t]{7}{*}{ Barriers } & Journey & 6 & 25 \\
\hline & Ambience & 12 & 38 \\
\hline & facilities/infrastructure of the city center & 18 & 31 \\
\hline & lack family friendliness & 2 & 7 \\
\hline & lack of diversity & 8 & 78 \\
\hline & focus on tourists & 3 & 7 \\
\hline & Retail & 16 & 50 \\
\hline \multirow[t]{3}{*}{ Suggestions } & City & 21 & 51 \\
\hline & Service & 13 & 28 \\
\hline & Retail & 27 & 55 \\
\hline Comparison Online-vs. & Advantages Online & 11 & 33 \\
\hline \multirow[t]{4}{*}{ Offline-shopping } & Disadvantages Online & 8 & 15 \\
\hline & Advantages offline & 18 & 39 \\
\hline & Preferences & 8 & 12 \\
\hline & combination of both channels & 8 & 19 \\
\hline
\end{tabular}




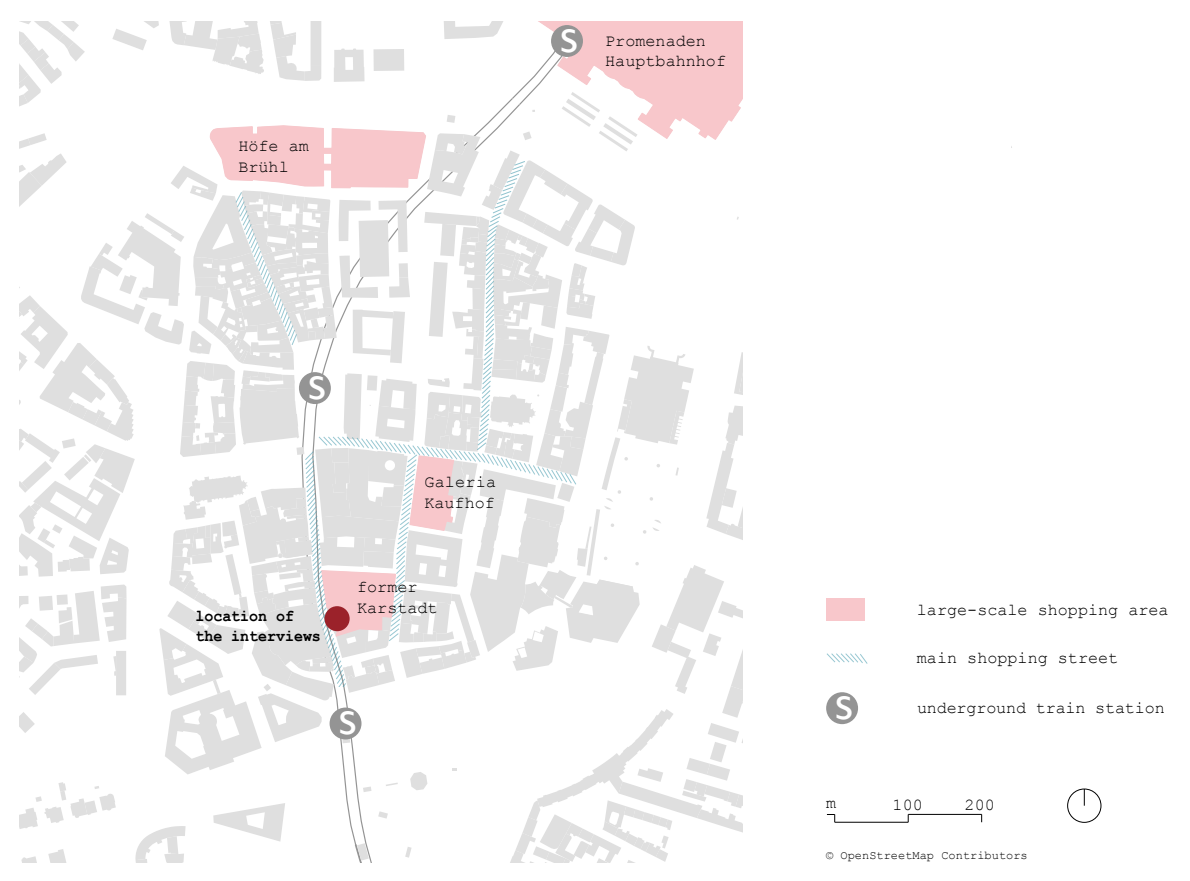

Figure 2: The location of the interviews within Leipzig's city center. Own elaboration based on Open Street Map Contributors/Geofabrik $\mathrm{GmbH} 2019$.

the map. Pretests both within the research group and with students help to determine whether the requirements for the prototype are appropriate.

The authors conduct qualitative go-along interviews with 70 visitors. Contrary to "conventional" interviews, the go-along follows a more interactive approach (Castrodale 2017) that helps to observe visitors' "perceptions, processing and navigation of their environments" (Carpiano 2009, 264). Go-along methods usually refer to interviews conducted on the move (Stiegler 2021). The research setting proposed by this study is located in only one static place. However, it is argued that discovering a virtual space together adds a digital layer to the go-along.

There is no strict interview guideline to ensure that each participant can be dealt with individually. This reduces the comparability between the interviews, on the one hand. On the other hand, it helps to understand the heterogeneous groups of visitors, as this type of explorative interview puts the focus on subjective information and opinions (Aghamanoukjan 2009). The authors expect the visitors to respond differently depending on their personal preferences and previous experience with digital tools. There is a notable difference between visitors concerning their technical and digital knowledge. On that basis, the authors divide the participants into different types of visitors and derive the prototype's benefits for each group.
Before using the prototype, the researchers explain its main functions to the interviewees. Visitors then try out the prototype using a provided screen. Based on a go-along approach, at least one researcher accompanies this process by observing the situation and placing stimuli to narrate (Kusenbach 2003). As there is no fixed interview guideline, it is the interviewee who sets the focus on the discussion topic. This allows the participants to associate with the prototype freely. However, there is a particular focus on how visitors interact with the prototype (usability) and on the demanded type of information (content). The key findings are transcribed during and after the interviews. Apart from that, the researchers take notes based on their observations.

\section{Results}

Based on the focus group interviews, digitalization is identified as one of the key factors to increase city center resilience in Leipzig. This is why the authors then develop a digital prototype and put it to the test by means of go-along interviews. 


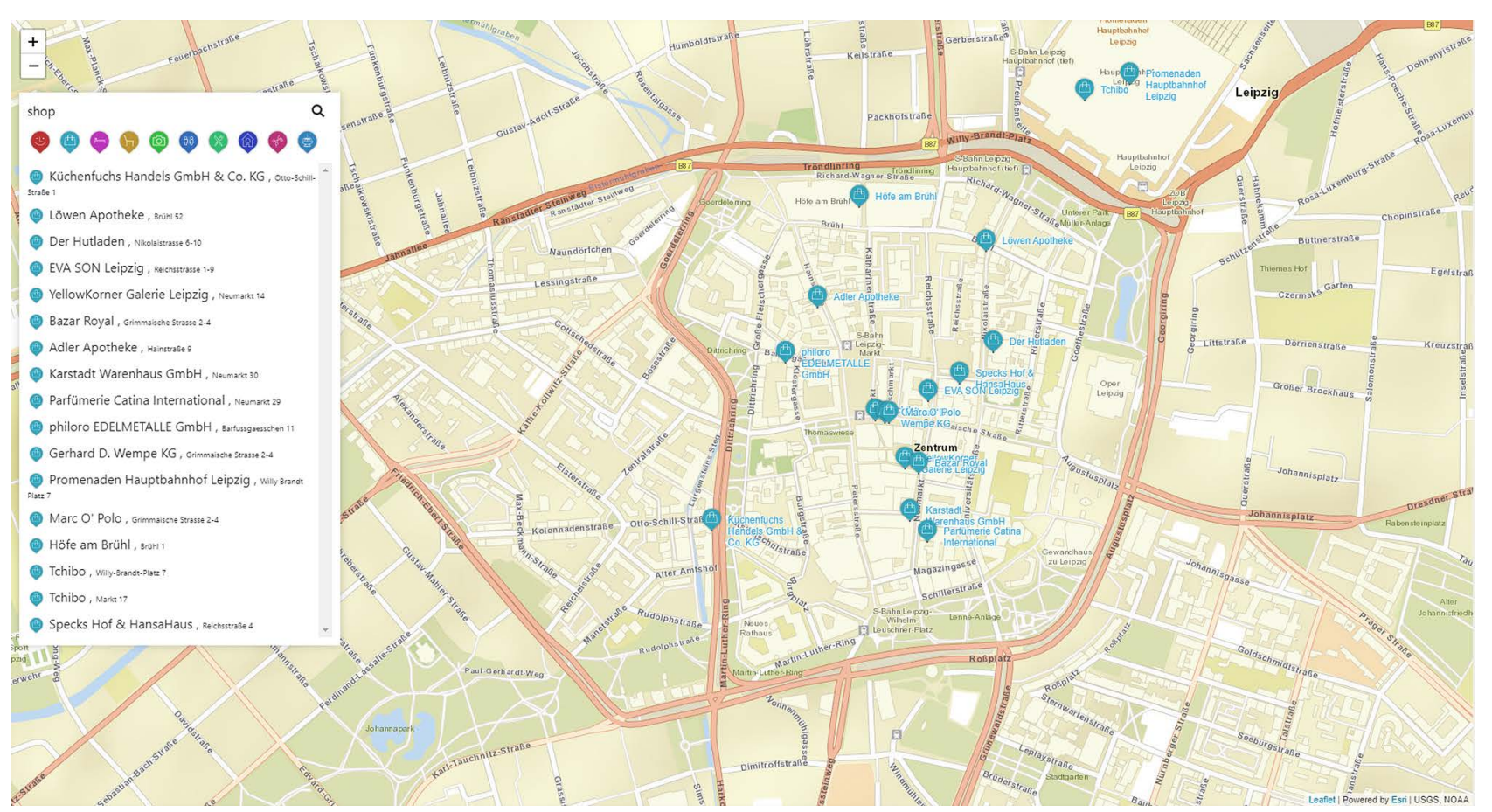

Figure 3: Screenshot of the prototype as a web application (own elaboration).

\subsection{Focus Group Interviews: Confirming Digitalization as Key Driver}

The inductive approach reveals three main categories, which are particularly interesting for this study: requirements for the city center, barriers for visiting the city center, and suggestions for improvement. The coding table shows that most participants determine opportunities and places for recreation as a central requirement. Due to the high number of visitors in the city center, most interviewees, particularly parents with children, perceive shopping in Leipzig's city center as stressful: "That's also a stress factor, driving until there. I would always prefer a district where it is quieter. In the city center, it is pretty noisy, especially with a child" (P2I3). Thus, a vital city center should offer recreation places, such as sitting opportunities, water stations, and green areas, where the visitors can take a break from crowded places.

Respondents also state additional requirements for certain facilities. On the one hand, it includes general aspects, for example, the availability of toilets, cleanliness of the center, high security, and cheaper tickets for public transport. On the other hand, the respondents point out additional services such as childcare, cultural offers, and a decentralization of the crowd as relevant elements of city center attractiveness, which are missing in Leipzig: "My youngest is four, the other is eight and they just find it too boring. There is a lack of playgrounds or something like that. You will end up buying on the internet because the kids don't want to go shopping" (P5I4). Thus, the above-mentioned elements would make the city center visit more comfortable and more convenient.

Beyond that, focus group participants highlight the need for diversity and lived experience. This includes a full range of retailers and service institutions as well as different entertainment elements and technologies (e.g., musicians, Segway-tours, mixed reality applications, etc.). According to the participants, global retail chain stores increasingly occupy the urban space of the city: "In Leipzig, I just notice that there are only these well-known brands and cheap shops that are everywhere" (P2I1). Nevertheless, several interviewees underline that city centers need to create a recognition value: "The face of a city should be preserved so that it remains recognizable and so that one city doesn't look like another" (P2I2). This aspect follows the identified challenges in research, namely the necessity for city centers to provide supplementary services apart from shopping (Wichner/Sörgel 2019; Gerber 2018, 197).

Closely connected to the before-mentioned requirement, several interviewees ask for a central information tool offering diverse content regarding the city center and the existing offer. This contains a listing of existent services, products, and special offers, especially from small retailers and businesses that lack a robust online pres- 
ence, as well as notices of current and upcoming events. However, this tool should further include information on the previously mentioned needs, such as availability of green areas, and up-to-date attendance (e.g., P5I1; P1I3; P2I3).

Furthermore, the respondents are discontent with several facilities. As already mentioned, it seems problematic that there are not enough sufficient toilets, dustbins, benches, playgrounds, and, especially, green areas or family-friendly offers available. Besides, the infrastructure is not satisfactory. Tickets for public transport are expensive, parking possibilities are either expensive or insufficient, and the journey itself is partially inconvenient. Additionally, there are some structural planning issues, construction noise, and frequent demonstrations that tend to discourage visits to the city center. The lack of search or filter options for products and services concerning local retailers' webpages or search machines concerning information about retail in Leipzig' city center aggravate this issue. A respondent explains: "If I went to the city center, I wouldn't even know which shop I had to go to get what I was looking for. That's why I prefer to search online right away" (P5I1).

In summary, the focus group participants state that Leipzig's city center increasingly loses its flair. One interviewee even expresses it as follows: “[...] I feel pressured as soon as I get there from all the shops and impressions, knowing that you actually don't need anything [...]" (P3I1). Some others agree and perceive this development as follows "So, for me, it's (Leipzig's city center) getting more and more foreign. You don't feel so closely connected anymore" (P5I5). Thus, the main obstacle is that the centers' ambience suffers, diminishing its attractiveness to visit, threatening its resilience.

In the discussion process, the focus group participants develop several solutions for city center visits. To reduce the crowds and the stress-level inside Leipzig's center, they suggest two ideas: 1 . modifying the opening hours and 2. using second floors and rooftops to better distribute people. Several respondents further mention that the city should provide pick-up-points and lockers for the purchases to comfort shopping. To create an interesting shopping experience, in contrast, many participants mention to enjoy concept-stores: "One could take up this concept [of pop-up-stores] and offer a space to young people and start-ups who want to present themselves" (P1I2).

Additionally, as pivotal solution for the above-mentioned issues, the interviewees describe a central information tool or platform providing access to many different types of data: “[...] it would be good to have a central site where they [guest visitors] can inform themselves. Where can I go to eat in the evening, where can I have something cleaned, where can I find a cobbler and a café'; so, complementary offers in the city" (P2I3). However, interviewees supplement that such a digital tool can be helpful not only for guest visitors but also for residents, especially when they look for something specific. In this context, some interviewees expand on this idea by adding that products and the place of location should be listed on this digital platform: "I would find that exciting if I can't find something, that I tell an app 'men's shoes' and it tells me 'Höfe am Brühl, first floor, three stores' [shopping center in the city center of Leipzig] (P3I4; P2I1, P4I3,). Further, this tool should integrate planning aid, which helps to organize a visit of the city center comfortably such as "[...] the best route and when there are fewer customers” (P113).

The analysis of these results shows that many suggested solutions are difficult to realize in the short term or require a lot of effort. However, the authors try to identify aspects that can be addressed within this study. Thereby, the comparison between the mentioned requirements and the infrastructure of the city of Leipzig reveals that many of the requested aspects do already exist in Leipzig's city center. Most respondents are simply not aware of the existing offerings, especially the availability of facilities such as sitting opportunities, water stations, toilets, banks, green areas, etc. Therefore, it is indispensable for the city to provide an information platform that allows visitors to orientate themselves and provide as many additional services and offerings as possible. The participants suggest a digital information platform as one solution that combines all these functions and helps not just tourists but also citizens themselves.

\subsection{Go Along: Evaluating and Improving the Prototype}

The prototype, a digital map of Leipzig' city center, incorporates most aspects named by the interviewees within the focus groups. Following, the qualitative go-along interviews examine the interactions between Leipzig's city center visitors and the prototype. First, the researchers want visitors to use the prototype and observe how it helps to attract them to the city center. Second, the interviewees are asked to name important functions and other requirements to refine the prototype, so that they are motivated to use it on a regular basis. The authors discuss the results by dividing the visitors into types based on their 
individual preferences to visit the city center, their digital abilities and interests. Among the sample, four types of visitors are identified: time-efficient visitors, non-digital visitors, digital visitors, and motivational visitors. Describing the visitor types helps to identify individual benefits of the prototype. The generated typology is expected to help adapt the prototype to the needs of different user groups. It also facilitates to understand which type of visitor profits most by using such a digital tool, while other visitors might have to be addressed with a completely different approach.

The first visitor type describes visitors who rarely go to the city center (time-efficient visitors). These are referred to as time-efficient because they only want to visit the city center out of a particular need, and they also want to leave as quickly as possible once their intentions have been met. As a consequence, these visitors perceive a stay in the city center as "way too exhausting" (ST1). Time-efficient visitors are mostly families with children or are accompanied by at least two people, which is in line with the findings of the focus group interviews. Their desire for technologies that improve navigation seems high, as their interaction with the prototype shows. The prototype thus provides information that is of considerable value for this type of visitor, such as the location of green spaces, benches, toilets etc.

The second type describes non-digital visitors who consistently reject the support of digital applications to visit the city center. These visitors are mostly older but also middle-aged individuals who are skeptical about digitalization in general. While using the prototype, they question the necessity of the application: "I would rather explore the city on foot without planning everything first" (ST2). The benefit of the prototype is thus highly questionable. This type of visitor might be addressed by alternative tools.

The third type are digital visitors. For them, low costs and high benefits play an important role to visit the city center and retail is their primary destination. They mainly use the city center as a showcase and only purchase

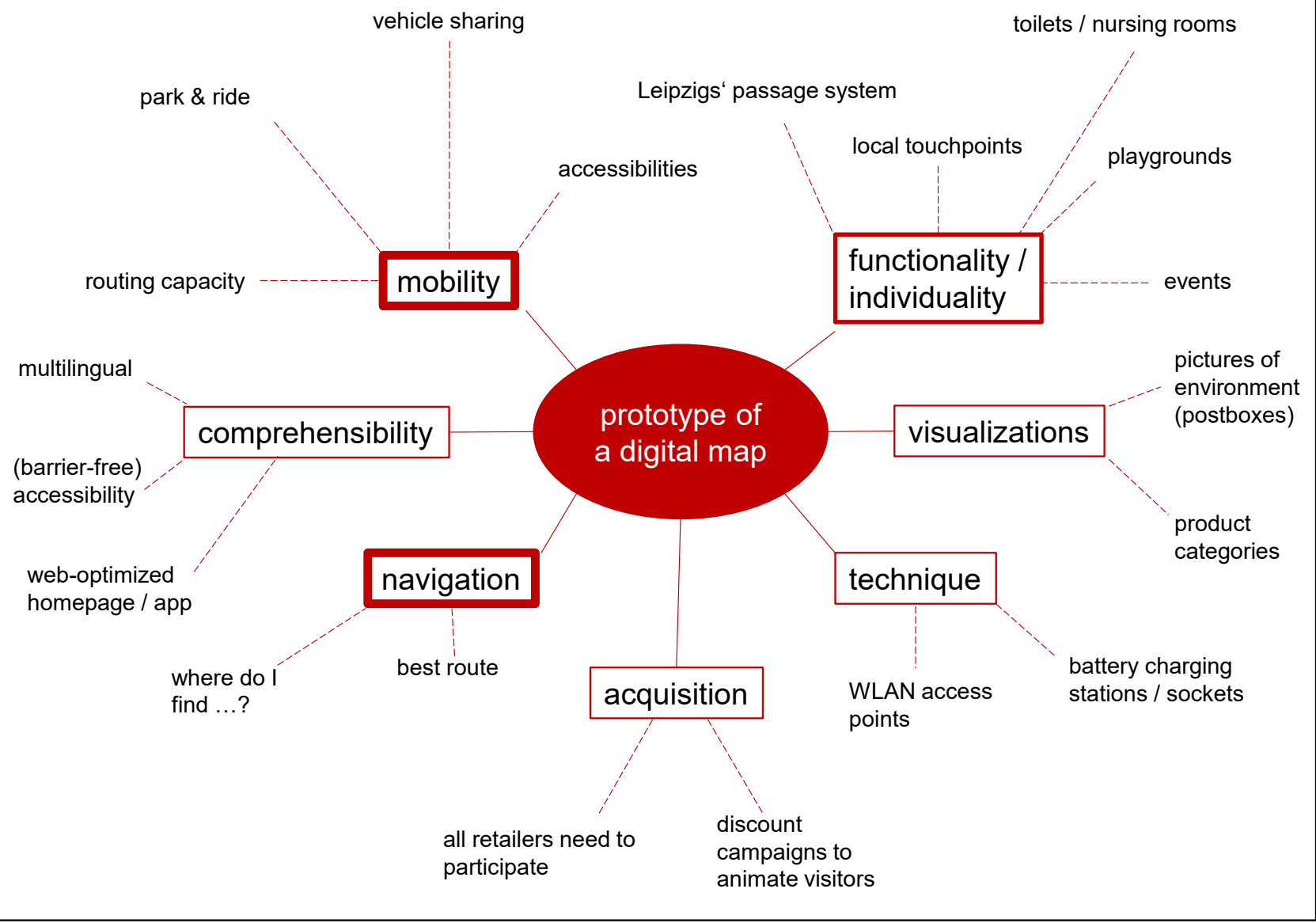

Figure 4: Visitors' suggestions for most relevant content in the prototype. Frequently named suggestions have stronger borders (own elaboration). 
in-store if there is a good deal. A respondent states: "I do not care where the product is from, as long as it is convenient for me to buy it" (ST3). This type mainly represents younger visitors aged between 18 and 30. At first, most of them do not seem to be too interested in the prototype. However, the more these interviewees get to know functions and possible extensions of the prototype, especially concerning digital tools for retail, the more they open up about their habits and preferences.

The fourth type are motivational visitors. These visitors mainly refer to retail when talking about the city center. Depending on the motivation of their purchase, they evaluate whether they want to shop in-store or online. If the motivation is an "unpleasant recurring shopping routine" (ST4), they rather purchase online or look for nearby shops. Against the background of their aversion to routines, this type of visitors seems to be more likely to combine shopping and other varying leisure activities in the city center. Most interviewees of the type are highly interested in the prototype and name potential extending functions that would help to increase their attraction to visit the city center.

The prototype proves to be particularly relevant for the time-efficient visitors and motivational visitors. For the first type, the variety of information mapped by the prototype is interesting because it eases the organization of a visit to the city center, to meet different interests. For motivational visitors, the prototype provides an overview of all stores in the city center. The prototype even shows stores that lie hidden. This surprise-like information can encourage leisure-oriented purchasing motivation. Motivational visitors are likely to combine shopping and other leisure activities in the city center. Showing synergies between different functions such as cultural sights, green areas, and gastronomy in the prototype can help to arouse this types interests.

For digital visitors, the prototype is interesting as long as its visual design and the functions appeal to them. Based on their extensive digital skills, this type of visitor has higher expectations of the prototype. They name innovative and missing tools that they would prefer. Hence, the prototype might help to reattract digital visitors to the city center as long as it contains specific and consumer-oriented information.

Overall, some interviewees assume that the prototype is more relevant for tourists since locals already know the city center well. When it comes to synergies between retail and other functions such as gastronomy, cultural sights or mobility, the map can also be interesting for locals. A comparison with google maps is obvious, which already portrays the city in a generally comprehensible way.
However, the additional information provided by the prototypes, such as seating, green spaces, water fountains, and restrooms, appeals to most visitors. They mainly welcome its possible way of the city centers' individual presentation. Most interviewees name mobility and navigation as essential elements of a commercial prototype (Fig. 4). They suggest mapping different forms of mobility, car sharing as well as tram and bicycle. Many visitors also highlight Leipzig's passages as a unique feature of the city center. They recommend putting it on a map to promote the passages and especially their vacancies, but mostly, to present a unique feature of Leipzig's city center. Some visitors note the lack of playgrounds for children not only on the map, but also in the city itself. Families with older children also desire non-commercial places for recreation. The interviewees frequently address (barrier-free) accessibility, referring to both the physical places and digital displays of the city center. On the one hand, high curbs and missing blind stripes aggravate the navigation. On the other hand, barrier-free access to digital information in the form of spoken functions or different language settings appears necessary.

Overall, visitors name requirements of the prototype that encourage frequent use (Table 3). Thus, the authors observe that the exchange between physical and digital requirements is becoming increasingly self-evident. There is the expectation to present peculiarities of the city center (no.3), such as the passages in Leipzig. The same applies

Table 3: Requirements for a commercial version of the prototype (own elaboration).

\begin{tabular}{ll}
\hline No. & Requirement \\
\hline 1 & Transparency (on how the information is generated) \\
\hline 3 & Trust and security (of the data) \\
\hline 4 & Presenting individualities of the city \\
\hline 5 & $\begin{array}{l}\text { Linking and specialization option (with e. g., mobility, spe- } \\
\text { cialization of range/products) }\end{array}$ \\
\hline 6 & $\begin{array}{l}\text { Individualization (defining own routes according to personal } \\
\text { interests) }\end{array}$ \\
\hline 7 & $\begin{array}{l}\text { Improving the existing local infrastructure (toilets, play- } \\
\text { grounds, non-commercial places) }\end{array}$ \\
\hline 8 & $\begin{array}{l}\text { Target group-specific information (accessibility, multilingual- } \\
\text { ism, etc.) }\end{array}$ \\
\hline 9 & $\begin{array}{l}\text { Pursue an open-source approach (free use, freely available } \\
\text { information) }\end{array}$ \\
\hline 10 & No advertising \\
\hline
\end{tabular}


to the topic of accessibility (no.8, no.9). Another important issue seems to be mistrust concerning digital applications (no.1, no.2, no.9, no.10). Unfortunately, visitors did not talk about how to create trust and security in digital applications. Finding reliable partners, publishing all relevant information, and providing a contact person to answer questions may help accept the application and encourage the use.

Consequently, there are several success factors and challenges to foster city center resilience.

- First, it needs local facilities as a basis to create synergies between local and digital functions. Without local facilities, digital solutions have no sense and represent only superficial and abstract urban structures.

- Second, diverse structures, characteristics and stakeholders thereby help to map the individual city center (Schade et al. 2018; Vural-Arslan et al. 2011; Litvin (2005).

- Third, new synergies of various services (playgrounds, toilets, non-commercial areas, etc.) are necessary because relying only on retail is threatening the resilience of city centers (Meerow et al. 2016).

- Fourth, retail also needs to become more diverse in the visitor's eyes. The growing number of chain stores and shop vacancies of local retailers minimize the attractiveness of the city center. It also contributes to the loss of the cities' ambience, which adds to the need for atmosphere-related elements, also considered as place attachment (Johnson et al. 2015).

- Fifth, digitalization contributes to the attractiveness of city centers in a way that it is a tool to illustrate these synergies (Schade et al. 2018). Thus, city center resilience requires the diversity of local, meaning physical and digital functions to adapt to major changes in the future.

\section{Conclusion}

Digitalization is a key driver of the transformation observed in retail and urban development, confirmed by the European ministers for urban matters in The New Leipzig Charter (BMI 2020). So far, digitalization has been formulated primarily as a challenge to existing urban structures. However, it can also contribute to the resilience of city centers, understood as the ability to adapt to these transformations and stay attractive for visitors. This paper sheds light on the demand side of exploring digitalization, as visitors' perceptions are often neglected in discourses overshadowed by technophilia and digitalization enthusiasm.
Two research aims were followed. First of all, factors were explored that contribute to Leipzig's city center resilience from the visitors' perspective. For this purpose, the authors conducted five focus group interviews with citizens from different social backgrounds. One of the central findings was that different groups expressed the need for a digital information platform, combining all the services and qualities offered in city centers. This contributes not only to enriching a stay in the center but also to informing from at home.

The second research objective was to build and test a prototype of a digital map covering Leipzig's city center, referring to the need of a digital information platform. This prototype was based on the requirements pointed out by the interviewees of the focus groups. The map included far more data compared to other providers (such as Google Maps), as it combined information of both retail and public spaces. This prototype was tested through go-along interviews with 70 participants in the city center. Two main conclusions were drawn. Firstly, from a technical perspective, modern technologies help to easily integrate spatial information on different levels, even if only a few (financial or time-related) resources are available. Secondly, the interviews illustrate that digitalization is a complementary concept that does not address each target group equally. This is why digital tools should be regarded as one further opportunity that enriches the city center experience. However, there should be different approaches that also reach the other (non-digital) types of visitors. The prototype presented here contributes to making services and supply transparent in a society, where online presence is becoming a crucial moment of success and efficiency. Thus, digital tools support city centers to adapt to ongoing transformation processes - and foster their resilience.

Further research has to be done to investigate how cities' information systems can implement these findings. The challenge is not only to collect relevant data but also to provide it in an appealing way to the citizens. Different models such as publicly subsidized projects, associations induced by the private sector or public-private partnerships should be evaluated to find out which constellation produces results that, in line with the Leipzig Charter 2020, address diverse people (BMI 2021). Even though digitalization is just one aspect to increase city center resilience, the development of digital solutions will become more relevant in the future. This has been proven by the current pandemic. Covid-19 accelerated digitalization, particularly in retail, with new online platforms mushrooming (Dannenberg et al. 2020; Chang/Meyerhoefer 2020). However, it is left unclear how these new tools integrate into the city, and how they can contribute to city center resilience. 


\section{References}

Aghamanoukjan, A./Buber, R./Meyer, M. (2009): Qualitative Interviews. In: Buber, R./Meyer, M. (eds.): Qualitative Marktforschung. Wiesbaden, 415-436.

Anttiroiko, A.-V. (2016): City-as-a-Platform: The Rise of Participatory Innovation Platforms in Finnish Cities. Sustainability, 8, 922, 1-31. https://doi.org/10.3390/su8090922.

Appel, A./Hardaker, S. (2021): Strategies in Times of Pandemic Crisis-Retailers and Regional Resilience in Würzburg, Germany. Sustainability, 13, 2643, 1-19. https://doi. org/10.3390/su13052643.

Balsas, C. J. L. (2014): Downtown resilience: A review of recent (re)developments in Tempe, Arizona. In: Cities, 36, 158-169.

Barata-Salgueiro, T./Erkip, F. (2014): Retail planning and urban resilience - An introduction to the special issue. Guest editorial. In: Cities, 36, 107-111.

Bartelheimer, C./Betzing, J.H./Berendes, C. I./Beverungen, D. (2018): Designing Multi-sided Community Platforms for Local High Street Retail. Twenty-Sixth European Conference on Information Systems (ECIS2018), Portsmouth, 1-17.

BBSR - Bundesamt für Bauwesen und Raumordnung (2019): Deutschland wächst - aber nicht überall. Bonn: Federal Institute for Research on Building, Urban Affairs and Spatial Development. Source: https://www.bbsr.bund.de/BBSR/DE/ Home/Topthemen/2018-bevoelkerung.html (02.09.2019).

Beckers, J./Weekx, S./Beutels, P./Verhetsel, A. (2021): COVID-19 and retail: The catalyst for e-commerce in Belgium? In: Journal of Retailing and Consumer Services, 62.

BMI - Bundesministerium des Inneren, für Bau und Heimat (2020): The New Leipzig Charter. The transformative power of cities for the common good. Source: https://www. nationale-stadtentwicklungspolitik.de/NSPWeb/SharedDocs/ Downloads/EN/the_new_leipzig_charter.pdf;jsessionid =9A198E40F0F1DCD0DCEA5E604E9E6413.live21322? blob=publicationFile \&v=4 (03.08.21)

Brańka, S./Coca-Stefaniak, J. A./Plichta, J. (2016): City Centres as Places for Strategic Cooperation through Active City Management - The Significance of Trade Entities. In: Scientific Annals of Economics and Business, 63(1), 125-133.

Brooks, D. (2001): Bobos in Paradise: The New Upper Class and How They Got There. New York.

Carpiano, R. M. (2009): Come take a walk with me: The "Go-Along" interview as a novel method for studying the implications of place for health and well-being. In: Health \& place, 15(1), 263-272.

Castrodale, M.A (2017): Mobilizing Dis/Ability Research: A Critical Discussion of Qualitative Go-Along Interviews in Practice. In: Qualitative Inquiry, 24(1), 45-55.

Chang, H. H./Meyerhoefer, C. D. (2021): COVID-19 and the demand for online food shopping services: Empirical Evidence from Taiwan. In: American Journal of Agricultural Economics, 103(2), 448-465.

City of Leipzig (2019): Einzelhandel. Source: https://www.leipzig. de/wirtschaft-und-wissenschaft/investieren-in-leipzig/ wirtschaftsstandort/daten-und-fakten/einzelhandel/ (02.09.2019).

Coca-Stefaniak, J. A./Carroll, S. (2015): Traditional or experiential places? Exploring research needs and practitioner challenges in the management of town centres beyond the economic crisis. In: Journal of Urban Regeneration and Renewal, 9, 38-45.

Dannenberg, P./Fuchs, M./Riedler, T./Wiedemann, C. (2020): Digital transition by COVID-19 pandemic? The German food online retail. In: Tijdschrift voor economische en sociale geografie, 111(3), 543-560.

Demko-Rihter, J./Ter Halle, I. (2015): Revival of high street retailingthe added value of shopping apps. In: Amfiteatru Economic Journal, 17(39), 632-645.

DeVerteuil, G. (2016): Resilience in the Post-Welfare Inner City. Voluntary sector geographies in London, Los Angeles and Sydney. Bristol: Policy Press.

Geo-Portal Hamburg (2021): https://geoportal-hamburg.de/ geo-online/ (09.08.2021).

Gerber, M. (2018): Citymanagement. In: Meffert, H./Spinnen, B./Block, J./BCSD e.V. (eds.): Praxishandbuch City- und Stadtmarketing, Wiesbaden, 191-204.

Gibson, C./Hardman, D. (1998): Regenerating urban heritage for tourism. In: Managing Leisure, 3(1), 37-54.

Glerean, N./Hulpi, M./Talman, K./Haavisto, E. (2019): Perception of nursing profession - focus group interview among applicants to nursing education. In: Scandinavian Journal of Caring Sciences, 33(2), 390-399.

Haase, A./Herfert, G./Kabisch S./Steinführer A. (2012): Reurbanizing Leipzig (Germany): Context Conditions and Residential Actors (2000-2007). In: European Planning Studies - EUR PLAN STUD, 20, 1-24.

Haefner, L./Sternberg, R. (2020): Spatial implications of digitization: State of the field and research agenda. In: Geography Compass, 14(12), 1-16.

Hagberg, J./Sundstrom, M./Egels-Zandén, N. (2016): The digitalization of retailing: an exploratory framework. In: International Journal of Retail \& Distribution Management, 44(7), 694-712.

Hart, C./Stachow, G./Cadogan J. W. (2013): Conceptualising town centre image and the customer experience. In: Journal of Marketing Management, 29(15/16), 1753-1781.

HDE/IFH (Handelsverband Deutschland \& IFH Institut für Handelsforschung) (2021): Online Monitor 2021. Source: https:// einzelhandel.de/index.php?option=com_attachments\&task= download\&id=10572 (12.07.2021).

HDE/IFH (Handelsverband Deutschland \& IFH Institut für Handelsforschung) (2019): Online Monitor 2019. Source: https:// einzelhandel.de/index.php?option=com_attachments\&task=d ownload\&id=10168 (10.11.2019).

Heinemann, G./Gaiser, C. (2016): Location-based Services - Paradebeispiel für digitale Adoption im stationären Einzelhandel. In: Digitale Transformation oder digitale Disruption im Handel. Heinemann, G./Gehrckens, H.M./Wolters, U.J./dgroup GmbH, Springer Fachmedien Wiesbaden, 241-257.

Herfert, G./Röhl, D. (2001): Leipzig - Region zwischen Boom und Leerstand. In: Brake K./Dangschat, J.S./Herfert, G. (Hrsg.): Suburbanisierung in Deutschland: Aktuelle Tendenzen. Wiesbaden, 151-162.

Hines, T. (2000): An evaluation of two qualitative methods (focus group interviews and cognitive maps) for conducting research into entrepreneurial decision making. In: Qualitative Market Research: An International Journal, 3(1), 7-16.

Holdack, E./Lurie, K./Fromme, H. (2020): The role of perceived enjoyment and perceived informativeness in assessing the 
acceptance of AR wearables. Journal of Retailing and Consumer Services. 10.1016/j.jretconser.2020.102259

Hopkins, P. E. (2007): Thinking critically and creatively about focus groups. In: Area, 39(4), 528-535.

Hübscher, M./Zur Lage, F./Ertle, L./Briem, K./Brucker, N. (2021): Revaluating “Germany's worst street”. Commercial gentrification on Leipzig's Eisenbahnstraße? In: DIE ERDE-Journal of the Geographical Society of Berlin, 152(1), 18-32.

IFH (Institut für Handelsforschung) (2019): Vitale Innenstädte 2018. Städteperformance, Kundenerwartungen und Kundenverhalten im Fokus. Source: https://www.ifhkoeln.de/vitale-innenstaedte (10.11.2019).

Jakobsen, H. (2012): Focus groups and methodological rigour outside the minority world: making the method work to its strengths in Tanzania. In: Qualitative Research, 12(2), 111-130.

Johnson, K. K. P./Kim, H.-Y./Mun, J. M./Lee, J. Y. (2015): Keeping customers shopping in stores: interrelationships among store attributes, shopping enjoyment, and place attachment. In: The International Review of Retail, Distribution and Consumer Research, 25(1), 20-34.

Jones, C./Livingstone, N. (2018): The 'online high street' or the high street online? The implications for the urban retail hierarchy. In: The International Review of Retail, Distribution and Consumer Research, 28(1), 47-63.

Kabisch, S./Koch, F./Gawel, E./Haase, A./Knapp, S./Krellenberg, K./Zehnsdorf, A. (2018): Urban Transformations: Sustainable Urban Development Through Resource Efficiency, Quality of Life and Resilience (Vol. 10). Cham.

Korzer, T./Hübscher, M./Schade, K./Ringel, J. (2020): Rethinking retail digitisation in urban settings. The case of Leipzig, Germany. In: Proceedings of the Institution of Civil Engineers Urban Design and Planning, 1-13.

Kusenbach, M. (2003): Street Phenomenology: The Go-Along as Ethnographic Research Tool. In: Ethnography, 4(3), 455-485.

Leichenko, R. (2011): Climate change and urban resilience. In: Current Opinion in Environmental Sustainability, 3(3), 164-168.

Litvin, S. (2005): Streetscape improvements in an historic tourist city a second visit to King Street, Charleston, South Carolina. In: Tourism Management, 26, 421-429.

Mayring, P. (2000): Qualitative Content Analysis. In: Forum: Qualitative Social Research 1(2), 1-10. Available at: <http:// www.qualitative-research.net/index.php/fqs/article/ view/1089>. Accessed 2 Sep 2019.

Meerow, S./Newell, J. P./Stults, M. (2016): Defining urban resilience: A review. In: Landscape and Urban Planning, 147, 38-49.

Nanda, A./Xu, Y./Zhang, F. (2021): How would the COVID-19 pandemic reshape retail real estate and high streets through acceleration of E-commerce and digitalization? In: Journal of Urban Management, 10(2), 110-124.

Nichols, C., (2011): The City as an Entertainment Machine. Lanham.

Nuissl, H./Rink, D./Steuer, P. (2005): The consequences of urban sprawl in a context of decline: the case of Leipzig. Available at: UFZ Discussion Paper, 7. https://www.econstor.eu/ handle/10419/45194 (02.09.2019).

Öner, O. (2017): Retail city: the relationship between place attractiveness and accessibility to shops. In: Spatial Economic Analysis 12, 1-20.

Open Street Map Contributors/Geofabrik GmbH (2019): Map of Leipzig. Source: https://www.geofabrik.de/de/index.html (04.10.2019).
Ozuduru, B. H./Varol, C./Ercoskun, O.Y. (2014): Do shopping centers abate the resilience of shopping streets? The co-existence of both shopping venues in Ankara, Turkey. In: Cities, 36, 145-157.

Patton, M.Q. (2002): Qualitative Research and Evaluation Methods. 3rd ed. Thousand Oaks.

Pazder, D. (2011): The Conception of Cultural Space Revitalization as a Way to Increase Downtown Attractiveness. A Case Study of Chosen Medium-Sized Towns in the Wielkopolska Region. In: Quaestiones Geographicae, 30, 63-67.

Rao, F. (2019): Resilient Forms of Shopping Centers Amid the Rise of Online Retailing: Towards the Urban Experience. Sustainability, 11, 3999, 1-25. https://doi.org/10.3390/su11153999

Sandahl, J./Lindh, C. (1995): Impact of improving the attractiveness of town centres. In: Transport Policy, 2(1), 51-56.

Schade, K./Hübscher, M./Korzer, T. (2018): Smart Retail in Smart Cities: Best Practice Analysis of Local Online Platforms. In: ICETE - Proceedings of the 15th International Joint Conference on e-Business and Telecommunications 1, 147-157.

Schade, K./Hübscher, M. (2018): Handelslagen der Zukunft: urban, vernetzt, digital? Ein Plädoyer für belebte Innenstädte in Zeiten der Digitalisierung. In: UrbanLab Magazin. Fachzeitschrift für Stadt- \& Regionalplanung. 3, 128-132.

Schmidt, Y. (2021): Mehr Leerstand durch Corona. Leipziger Volkszeitung, 08.07.2021.

Sharifi, A./Khavarian-Garmsir, A.R./Kummitha, R.K.R. (2021): Contributions of Smart City Solutions and Technologies to Resilience against the COVID-19 Pandemic: A Literature Review. Sustainability, 13, 8018. https://doi.org/10.3390/su13148018.

Singleton, A.D./Dolega L./Riddlesden D./Longley, P.A. (2016): Measuring the spatial vulnerability of retail centres to online consumption through a framework of e-resilience. In: Geoforum, 69, 5-18.

Sparks, L. (2021): Towns, High Streets and Resilience in Scotland: A Question for Policy? Sustainability, 13, 5631, 1-14. https://doi. org/ 10.3390/su13105631

Sperle, T. (2012): Was kommt nach dem Handel? Umnutzung von Einzelhandelsflächen und deren Beitrag zur Stadtentwicklung (Ph.D. thesis, University of Stuttgart).

Stadt Leipzig (2021): Einwohnerzahl und Bevölkerungsentwicklung in Leipzig. Available at: <https://www.leipzig.de/ buergerservice-und-verwaltung/unsere-stadt/statistikund-zahlen/einwohner-und-bevoelkerungsentwicklung/>. Accessed 27 Jul 2021.

Stadt Leipzig (2020): Monitoringbericht Einzelhandel 2019. Kleinräumiges Monitoring der Stadtentwicklung. Leipzig.

Stepper, M. (2016): Innenstadt und stationärer Einzelhandel ein unzertrennliches Paar? Was ändert sich durch den Online-Handel? In: Raumforschung und Raumordnung, 74, 151-163.

Stiegler, S. (2021): On doing go-along interviews: Toward sensuous analyses of everyday experiences. In: Qualitative Inquiry, 27(3-4), 364-373.

Thomas, D.R. (2006): A General Inductive Approach for Analyzing Qualitative Evaluation Data. In: American Journal of Evaluation, 27(2), 237-246.

Tonkiss, F. (2004): Using Focus Groups. In: Seale C (ed): Researching society and culture, Sage, London, 193-206. 
Vainikka, J.T. (2015): Reflexive Identity Narratives and Regional Legacies. In: Tijdschrift voor economische en sociale geografie, 106(5), 521-535.

Villa, R./Monzón, A. (2021): Mobility Restrictions and E-Commerce: Holistic Balance in Madrid Centre during COVID-19 Lockdown. Economies, 9(2), 1-19.

Vural-Arslan, T./Dostoglu N./Köprülü-Bagbanci, Ö./Akincitürk, N. (2011): Sustainable revitalisation as a tool for regenerating the attractiveness of an inner-city historic commercial district: 'Han District' as a case. In: URBAN DESIGN International, 16(3), 188-201.

Wahlberg, 0. (2016): Small town centre attractiveness: evidence from Sweden. In: International Journal of Retail \& Distribution Management, 44, 465-488.

Walker, B./Holling, C./Carpenter, S./Kinzig, A. (2004): 'Resilience, adaptability and transformability in social-ecological systems', Ecology and Society, 9(2): 5.

Wang, M.C./Gordon, E.W. (1994): Educational research in inner-city America. Challenges and prospects. New York: Routledge.
Weltevreden, J.W.J./Rietbergen, T.V. (2007): E-Shopping Versus City Centre Shopping: The Role of Perceived City Centre Attractiveness. In: Tijdschrift voor economische en sociale geografie, 98(1), 68-85.

Wichert, J./Fromme, H. F./Ludwig, A. (2019): Instrumente der Interaktionsintegration im Omni-Channel Handel. In: HMD Praxis der Wirtschaftsinformatik. https://doi.org/10.1365/ s40702-018-00491-5.

Wichner, D./Sörgel, C. (2019): Große Leerflächen: Leipzigs Einzelhandel kämpft mit Strukturproblem. Source: https:// www.jll.de/de/presse/grosse-leerflaechen-leipzigseinzelhandel-kaempft-mit-strukturproblem (02.09.2019).

Wrigley, N./Dolega, L. (2011): Resilience, fragility, and adaptation: new evidence on the performance of UK high streets during global economic crisis and its policy implications. In: Environment and Planning, 43, 2337-2363.

Zenker, S. (2011): How to catch a city? The concept and measurement of place brands. In: Journal of Place Management and Development, 4(1), 40-52. 